\title{
CRISIS NOW: БИЗНЕС-КЕЙС, ПРИВЕДШИЙ К ПРЕОБРАЗОВАНИЮ КРИЗИСНОЙ САУЖБЫ. ОПЫТ ШТАТА АРИЗОНА, США
}

\author{
David W. Covington \\ RI International, Финикс, штат Аризона, США \\ CRISIS NOW: THE BUSINESS CASE RESULTING IN A TRANSFORMATION OF CRISIS CARE. \\ THE EXPERIENCE OF ARIZONA IN THE UNITED STATES
}

David W. Covington - мицензированный профессиональный консультант, магистр делового администрирования (Researcher ID: AAH-1910-2020; ORCID iD: 0000-0002-7311-1751). Место работы и должность: Исполнительный директор и президент RI International. Адрес: 2701 N. 16 th St. Suite 316, Финикс, штат Аризона, 85006, США. Эмектронный адрес: David.Covington@riinternational.com

Information about the author:

David W. Covington, LPC, MBA (Researcher ID: AAH-1910-2020; ORCID iD: 0000-0002-7311-1751). CEO \& President, RI International. Address: 2701 N. 16 ${ }^{\text {th }}$ St. Suite 316, Phoenix, AZ 85006, USA. Email: David.Covington@riinternational.com

Каждый день диспетчеры служб экстренного реагирования получают тысячи звонков, связанных с кризисными ситуациями в сфере психического здоровья. В большинстве случаев первыми на место выезжают полицейские, у которых нет другой возможности, кроме как отвезти человека в отделение скорой помощи или в участок. Люди могут ждать несколько часов или даже дней, чтобы получить консультацию психиатра. Во многих случаях их отпускают, не оказав необходимой помощи или не составив плана лечения. В ответ на эту ситуацию, Национальный альянс действия в США сформировал целевую группу по кризисным службам, которая в 2016 году выступила с моделью «Crisis Now: преобразование служб в пределах доступности». Чтобы справиться с задачей и изменить кризисные службы RI International объединился с Национальной ассоциацией директоров программ штатов в сфере психического здоровья и создал бизнес-кейс для Crisis Now, чтобы определить континуум оказания помощи. С этой моделью Индекс соответствия между потребностями и клиническим ответом на кризис повысился в 6 раз. Модель сократила расходы и потери отделений скорой помощи на 37 миллионов долларов, снизила потенциальные расходы на пациентов психиатрических стационаров на 260 миллионов долларов, а также сберегло время работы полицейских, эквивалентное 37 ставкам (по данным штата Аризона, 2017 год). Количество перенаправленных в острый стационар из кризисного центра за этот период составило 8938 человек.

Ключевые слова: кризис, профилактика суицида, Crisis Now, Аризона, США

Каждый день в США диспетчеры служб экстренного реагирования получают тысячи звонков, связанных с кризисными ситуациями, вызванными проблемами в сфере психического здоровья. В большинстве случаев первыми выезжают на место полицейские. В США полицейские обычно проводят 7-10\% времени, отвечая на эти вызовы. Хотя полицейские очень стараются, у них практически нет альтернатив: им приходится доставлять человека в состоянии психического кризиса, либо в отделение скорой помощи, либо запирать в участке, в камере предварительного заключения. В таких случаях, люди могут провести в ожидании часы и даже дни, чтобы получить специализированную кризисную помощь от профессионалов в сфере психического здоровья. Этот процесс называется "psychiatric boarding” (психиатрический пансион). В некоторых
Every day in the United States, thousands of calls are received by emergency dispatchers in response to mental health crisis situations. In the overwhelming majority of these cases, the first contact that a person receives is from a Police Officer. In the US, Police Officers routinely spend between $7-10 \%$ of their time responding to these calls. Despite the best intentions, Police officers often have little option but to take people in a mental health crisis to Emergency Response departments or to a jail cell. In these cases, individuals can sit for hours or days waiting for a chance to receive specialized crisis care by mental health professionals. This process is called "psychiatric boarding". In some cases, those in crisis may be released without appropriate care and without a clear plan for recovery. 
случаях человека в кризисе могут освободить без необходимой медицинской помощи и чёткого плана по выздоровлению.

Эта система не только губительна для людей в кризисе и не отвечает их нуждам, но и бессмысленно дорого обходится обществу. По оценкам, в США каждый визит пациента, требующего психиатрической помощи, в отделение скорой помощи стоит 2264 доллара [1]. Это стоимость содержания человека в кризисе в безопасности, пока ему не найдётся место. Этим местом чаще всего оказывается закрытая психиатрическая больница. В США отделения скорой помощи перенаправляют пациентов в дорогостоящие психиатрические стационары чаще, чем это предполагает клиническая модель.

Несмотря на затраты в текущей системе лечения людей в кризисе, исходы неутешительны.

Необходимость преобразовать кризисную психиатрическую помощь очевидна.

Смерти в результате самоубийства: В США в 2016 году около 45000 человек покончили с собой. Показатели самоубийств растут с 1999 по 2015 год, и это касается всех рас, полов, уровней урбанизации [2]. Всемирная организация здравоохранения утверждает, что каждые 40 секунд кто-то погибает, убивая себя [3]. При этом на одного погибшего обычно приходится около 20 человек, которые совершают суицидальные попытки, но выживают. Суицид - десятая причина смерти в США, и $80 \%$ погибших от суицида обращались в медицинские службы за год до смерти. В то время как показатели суицида различаются в разных странах, ни одна страна не достигла нулевой смертности от самоубийств.

Невыразимая боль: В своём выступлении «Почему поведенческая медицинская служба должна быть доступна студентам в кризисных состояниях» Миша Кесслер [4] говорил о своём опыте, когда на втором курсе университета он начал избегать людей, считая себя обузой для друзей и семьи. Эти болезненные размышления вместе с бессонницей привели к лихорадочному возбуждению. Он думал, что нашёл решение, возможность избежать боли: он залез на подоконник в своей комнате в общежитии на шестом этаже и был готов спрыгнуть. Но он посмотрел назад, в комнату, и увидел своё отражение в полный рост в зеркале шкафа, и тут его тревога и ненависть к себе превратилась в ярость. Вернувшись в комнату, он встал напротив зеркала и ударил по нему несколько раз изо всех сил, порезав руку. Это действие успокоило Кесслера, а также заставило понять всю тяжесть ситуации. «Я так себя ненавидел, что разбил зеркало - своё отражение в нем. Тут я понял: “Так, это серьёзно. Мне нужна помощь”». Кесслер борется за преобразование медицинской по-
This system is not only detrimental to those that are in crisis but is unnecessarily expensive to a community while still not addressing the needs of an individual in crisis. In the US, it is estimated that each Emergency Department visit for a mental health crisis costs $\$ 2,264$ [1]. This is the cost of keeping a person in crisis safe while an appropriate disposition is found. These dispositions tend to be a referral to an inpatient psychiatric hospital. In the US, Emergency Departments refer to costly inpatient psychiatric hospitals more often than clinical modeling would anticipate.

Despite the high cost of these common current systems in treating those in crisis, outcomes are increasingly poor.

The need to transform mental health crisis care is clear.

Deaths by suicide: In the United States, there were nearly 45,000 deaths by suicide in 2016. Suicide rates increased across all races, genders, age groups, and urbanization levels from 1999 to 2015 [2]. The World Health Organization states about one person dies by suicide every forty seconds [3]. That statistic does not even include the approximate twenty people who attempt to die by suicide to the one person who dies by suicide. It is the $10^{\text {th }}$ leading cause of death in the United States and $80 \%$ of the victims in the US saw a healthcare professional in the year prior to their death. While the suicide rates vary per country, no country has reached the suicide rate of zero.

Unspeakable pain: In \#CrisisTalk: Misha Kessler on Why Behavioral Healthcare Must be Accessible to Students in a Crisis [4], Kessler spoke on his experiences when he was a sophomore when he began to increasingly isolate himself, believing he'd become a burden to friends and family. These ruminating thoughts, combined with insomnia, reached a fever pitch. He thought he found his solution, an escape from pain, when he crawled out a windowsill of his dorm room, six stories above the ground, and willed himself to jump. His eyes were drawn back to the dorm room, and in seeing his image in the full length, closet mirror, Kessler's anxiety, and self-hatred turned into rage. Launching himself back into the room, he stood in front of the mirror and punched it repeatedly, slicing his hand. The action calmed Kessler, but also made him realize the severity of the situation. "I hated myself so much that I punched out the mirror: my reflection. That was the moment when I knew, 'Okay, this is serious. I need help."” Kessler advocates for the need to transform behavioral healthcare to be accessible to students in a crisis. 
мощи, чтобы она стала доступна студентам в кризисе.

Психиатрическая помощь не должна исходить от полицейских: По всей стране в США есть полицейские отделения, которые больше не выезжают по вызову, если есть подозрение, что может произойти «суицид с помощью полицейского» ("suicide by cop" - когда полицейскому приходится стрелять в человека на поражение, прим. перевод.). Около 100 таких случаев происходит ежегодно, это около $10 \%$ смертей в полицейских перестрелках. Рон Бруно, исполнительный директор Crisis Intervention Team Utah (Команды кризисного вмешательства в штате Юта) и второй вице-президент Crisis Intervention Team International (Международной команды кризисного вмешательства), говорит, что таковы настроения в правоохранительных органах по всей стране, но быстро добавляет, что людей нельзя оставлять в кризисе. «Что-то нужно делать, и, поэтому, нам требуется изучить нашу систему кризисного реагирования в целом, выделив чёткие роли для правоохранительных органов и для здравоохранения». Бруно утверждает, что правоохранительные органы должны играть ключевую роль в системе реагирования на психиатрический кризис, но она должна поддерживать психиатрическую систему и применяться только в случае необходимости. «Мы должны поставить под сомнение убеждение, будто кризисная психиатрическая помощь должна исходить от полицейских» [5].

Есть и другой путь. При таком решении люди в психиатрическом кризисе избегают тюрем и больниц: их везут в центры кризисного восстановления и центры психического здоровья. Модель Crisis Now предлагает набор инструментов, которые обеспечивают помощь любому человеку, в любое время и в любом месте.

Национальный альянс действия по предотвращению суицидов (Альянс действия) созвал целевую группу по кризисным службам, в которой приняли участие 30 американских экспертов по кризисным ситуациям: вместе они решали, чего не хватает, и что необходимо психиатрическим службам в США. Преобразование кризисной помощи необходимо, чтобы обеспечить реагирование на психиатрический кризис, чтобы помочь излечению, дать надежду и достичь заветной цели Ноль суицидов (Zero Suicide - международное движение в поддержку этой цели, прим. перевод.), когда люди перестанут погибать из-за самоубийств. В соответствии с этой моделью, Альянс действия, Целевая группа по кризису опубликовала в 2016 году брошюру «Crisis Now: Преобразование служб в пределах доступности» [6].

Отчёт показал, что есть проблемы, которые требуется решить, чтобы разрешить кризис в системе психиатрической помощи. Проблемы, которые обнаружила группа Альянса действия таковы:
Mental health care shouldn't come in a police car: There are police departments throughout the United States that no longer answer calls they believe could result in "suicide by cop." Around 100 shootings like this happen each year, making up roughly $10 \%$ of fatal police shootings. Ron Bruno, executive director of CIT Utah and $2^{\text {nd }}$ vice president at CIT International, says this is a philosophy taking hold in law enforcement agencies all over the country, but he quickly points out, people can't just be left in distress. "Something has to be done, and that's why we need to examine our crisis response system as a whole, carving out clear roles for law enforcement and mental health services." Bruno says that law enforcement has a critical part to play in the mental health crisis response system, but it needs to be in a position of support to the mental healthcare system and only when necessary. "We have to challenge the belief that mental health crisis services must come in a police car." [5].

There is another way. A way that those persons in a mental health crisis are diverted from jails and hospitals to Crisis Recovery Centers and mental health centers.

The Crisis Now model offers a framework of mental health crisis tools that converge to provide care to any person, anywhere, at any time.

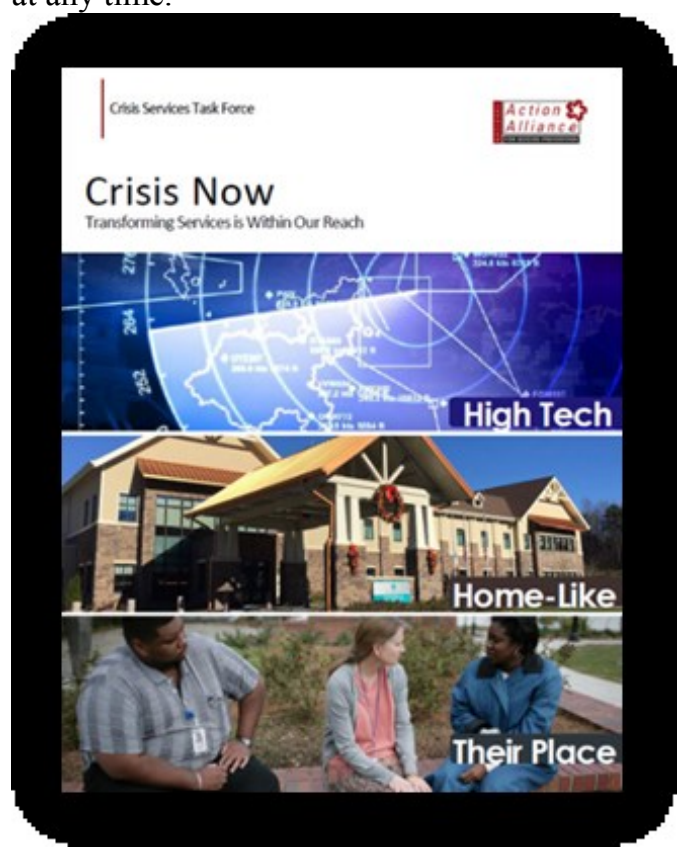

The National Action Alliance for Suicide Prevention (Action Alliance) convened the Crisis Services Task Force with 30 consensus US experts on crisis to address the gaps and needs of mental health care in the United States. A transformation of crisis care is needed to provide a response to mental health crisis to enable us to find recovery, hope, and to make it 
- Кризисная служба часто оказывается предпочитаемой и самой эффективной помощью для людей в кризисе.

- Отсутствие ключевых элементов успешной кризисной помощи в многих сообществах.

- Предложения по реформированию психиатрической службы существуют, но они не охватывают кризисную помощь.

- Равенство в получении психиатрической помощи и расширение охвата.

Отчёт также обнаружил ключевые элементы, которые формируют основу для эффективной кризисной психиатрической поведенческой помощи. Они следующие:

1. Кризисные колл-центры на уровне области или штата, координируемые в реальном времени.

2. Мобильные кризисные бригады, работающие 24/7 и расположенные в центральных узлах.

3. Краткосрочные, «подострые» программы стабилизации в условиях жилищного кризиса.

4. Базовые принципы и практики кризисной помощи.

Бизнес-модель Crisis Now.

Необходима эффективная, действенная модель. Она должна обеспечить основу для выполнения ключевых элементов, и помощь должна быть доступной и практичной. Crisis Now обеспечивает такую основу, описанную Целевой группой по кризису от Альянса действия:

- Высокотехнологичные кризисные колл-центры.

- Мобильные кризисные бригады 24/7.

- Программы стабилизации в кризисе.

- Базовые принципы и практики.

Кризисные колл-центры на уровне региона или штата являются центральными узлами, которые с помощью различных средств связи координируют помощь. Они обладают большим объёмом данных для улучшения выполнения задач и отчетности. Одновременно колл-центры обеспечивают поддержку людей в кризисе и их семей.

Удобно расположенные мобильные кризисные бри$2 a d b l, 24 / 7$. Мобильные кризисные бригады приезжают и поддерживают человека в кризисе на месте. Программы должны включать работников по контракту и медицинский персонал.

Краткосрочные «подострые» программы стабилизации в условиях жилищного кризиса. Эта программа краткосрочной «подострой» помощи людям, которым нужна поддержка и наблюдение, но не в отделении скорой помощи или стационаре, менее затратна и не требует помещения в психиатрическую больницу. Модель «Приюта» (Retreat model) доказывает, что реально избежать «психиатрического пансиона», чтобы пребы- possible to reach the goal of Zero Suicide, in which there are NO deaths by suicide. As a framework, the Action Alliance's Crisis Task Force in 2016 published the Crisis Now: Transforming Services is Within Our Reach [6].

The report showed that there are significant areas that must be addressed in order to meet the mental health crisis. The issues that the Action Alliance Crisis Task Force found include:

- Crisis care often being the preferred and most efficient care for people in crisis.

- The absence of core elements of successful crisis care in many communities.

- Mental health reform proposals that are on the table but fail to seize the opportunity to improve crisis care

- Mental health parity legislation and coverage expansion.

The report also discovered core elements that form the framework for delivering effective behavioral health crisis care. The core elements are the following.

1. Regional or statewide crisis call centers coordinating in real-time

2. Centrally deployed, $24 / 7$ mobile crisis

3. Short-term, "sub-acute" residential crisis stabilization programs

4. Essential crisis care principles and practices

The Crisis Now Business Model

An effective, efficient model is needed. It must provide the framework of delivering the core elements while assuring care is accessible and practical. Crisis Now provides that framework utilizing the core elements and recommendations of the Action Alliance's Crisis Task Force.

Regional or statewide crisis call centers

Crisis call centers provide a central hub through technology to coordinate across a system of care. They leverage a high volume of data to improve performance and accountability. Simultaneously, the call center provides high-touch support to individuals and families in crisis.

Centrally deployed, 24/7 mobile crisis

Mobile crisis offers outreach and support where people in crisis are. Programs should include contractually required response times and medical backup.

Short-term, "sub-acute" residential crisis stabilization programs

These programs offer short-term "subacute" care for individuals who need support and observation, but not ED holds or medical inpatient stay, at lower costs and without the overhead of hospital-based acute care. The 
вание в психиатрическом стационаре предоставлялось только тем, кому это действительно нужно, и обеспечивать максимум возможностей для восстановления [7].

Базовые принципы и практики кризисной помощи. Они должны включать ориентацию на выздоровление, помощь с учетом травматического опыта, значительное задействование равных среди персонала (peers, «равные» - люди, пережившие схожие психиатрические кризисы, но восстановившиеся после лечения и выбравшие помогать другим кризисным пациентам, прим. перевод.), приверженность идеям Zero Suicide / Suicide Safer Care (движения Ноль суицидов, Безопасная помощь при суицидах), а также идеям безопасности для потребителей, и взаимодействие с правоохранительными органами.

Crisis Now в действии.

В одном округе в Аризоне, где модель Crisis Now воплощена полностью, мы видим её результативность. В 2016 году правоохранительные органы города Финикса отвечали на вызовы 22000 людей в кризисе, напрямую перевозив их в кризисные центры или передавая мобильным бригадам, минуя отделения скорой помощи. Это значительно сократило расходы благодаря следующему:

- индекс соответствия между потребностями и клиническим ответом на кризис увеличился в 6 раз;

- снизились потенциальные расходы на пребывание пациентов в стационаре на 260 млн долларов;

- сберегло время работы полицейских, эквивалентное 37 ставкам;

- сберегло 37 миллионов долларов для отделений скорой помощи; 45 лет.

- сократило общий «психиатрический пансион» на

Инструменты оценки кризисной системы.

Crisis Now - единственная кризисная система, которая поддерживается Национальной ассоциацией директоров штатов программы психического здоровья (National Association of State Mental Health Program Directors) и Международной командой кризисного вмешательства. Множество штатов теперь внедряют эту модель в свои системы. Несколько инструментов было разработано для поддержки и оценки достоверности модели.

Каков поток в вамей кризисной системе? Люди поступают в кризисную систему, приходя самостоятельно, или их привозят мобильные бригады, или перенаправляют колл-центры, лечащие врачи, полиция. Однако большинство направляются из больничных отделений скорой помощи. Этот инструмент учитывает, сколько обращений происходит относительно всего населения в регионе, выдавая ежемесячный поток кризисных пациентов (Monthly Crisis Flow).
Retreat model shows a substantial effort to tackle the scourge of psychiatric boarding and ensure psychiatric inpatient capacity is maximized and available for those most in need, but with the strongest possible recovery approach [7]. tices

Essential crisis care principles and prac-

These must include a recovery orientation, trauma-informed care, significant use of peer staff, a commitment to Zero Suicide / Suicide Safer Care, strong commitments to safety for consumers and staff, and collaboration with law enforcement.

Crisis Now in Action

In one county in Arizona where the Crisis Now model is utilized to full fidelity, we see the impact possible when the model is implemented. In 2016, the metro area Phoenix law enforcement engaged 22,000 people in crisis transferring them directly to crisis facilities and mobile crisis without visiting a hospital ED. The change provided significant savings by doing the following.

- Improved Crisis Clinical Fit to Need (CCFN) by $6 \mathrm{x}$.

- Reduced potential state inpatient spend by $\$ 260$.

- Saved the equivalent of 37 FTE Police Officers (calculated by Arizona data, 2017).

- Saved hospital EDs \$37m in avoided costs/losses.

- Reduced total psychiatric boarding by 45 years (Calculated from "Impact of psychiatric patient boarding in EDs", 2012) [1].

Tools for Assessing a Crisis System

Crisis Now is the ONLY crisis system to be endorsed by the National Association of State Mental Health Program Directors (NASMHPD) and CIT International. Multiple states are now replicating and implementing the model into their own system. A range of tools has been developed to support and ensure fidelity to the model.

How Does Your Crisis System Flow? Individuals flow into the crisis system from walk-ins, mobile teams, crisis lines, primary care providers, and Police. However, most referrals flow through the Hospital Emergency Departments. The tool considers how many individuals flow through based on the total population for the region giving the amount of Monthly Crisis Flow. However, that is just part of the picture. The LOCUS Levels of Care helps to identify the level of need so that individuals are matched to the appropriate clinical care. 
Калькулятор проекций системы Crisis Now для штата Индиана Crisis Now Crisis System Calculator Projections - Indiana

таблица 1 / Table 1

\begin{tabular}{|c|c|c|}
\hline Показатель & $\begin{array}{l}\text { Без кризисной помощи } \\
\text { No Crisis Care } \\
\end{array}$ & Crisis Now \\
\hline $\begin{array}{l}\text { Число кризисных эпизодов ежегодно } \\
\text { \# of Crisis Episodes Annually (200 / } 100000 \text { Monthly) }\end{array}$ & 160605 & 160605 \\
\hline $\begin{array}{l}\text { Число сразу же отправленных в острый стационар } \\
\text { \# Initially Served by Acute Inpatient }\end{array}$ & 109211 & 22485 \\
\hline $\begin{array}{l}\text { Перенапраправленные в острый стационар из кризисного центра } \\
\text { \# Referred to Acite Inpatient From Crisis Facility }\end{array}$ & - & 8938 \\
\hline $\begin{array}{l}\text { Общее число пациентов в остром стационаре } \\
\text { Total \# of Episode in Acute Inpatient }\end{array}$ & 109211 & 31422 \\
\hline $\begin{array}{l}\text { Число необходимых коек в остром стационаре } \\
\text { \# of Acute Inpatient Beds Needed }\end{array}$ & 2327 & 670 \\
\hline $\begin{array}{l}\text { Oбщая стоимость коек в остром стационаре } \\
\text { Total Cost of Acute Inpatient Beds }\end{array}$ & $\$ 679537905$ & $\$ 195517046$ \\
\hline $\begin{array}{l}\text { Перенаправленные на краткосрочное пребывание после } \\
\text { стабилизационных кресел } \\
\text { \# Referred to Short-Term Bed From SStabilization Cha }\end{array}$ & - & 35751 \\
\hline $\begin{array}{l}\text { число необходимых кризисных коек } \\
\text { \# of Crisis Beds Needes }\end{array}$ & - & 272 \\
\hline $\begin{array}{l}\text { Обшая стоимость кризисных коек / кресел } \\
\text { Total Cost of Crisis Facility Beds / Chairs } \\
\end{array}$ & $\$-$ & $\$ 79445976$ \\
\hline $\begin{array}{l}\text { Число изначально обслуженных в центре кризисной стабилизации } \\
\text { \# Initially Served by Crisis Stabilization Facility }\end{array}$ & - & 86727 \\
\hline $\begin{array}{l}\text { Число направленных в кризисный центр мобильной бригадой } \\
\text { \# Referred to Crisis by Mobile Team }\end{array}$ & - & 15418 \\
\hline $\begin{array}{l}\text { Общее число случаев в кризисном центре } \\
\text { Total \# of Episodes in Crisis Facility }\end{array}$ & - & 102145 \\
\hline $\begin{array}{l}\text { Число необходимых кризисных стабилизационных кресел } \\
\text { \# of Crisis Stabilization Chairs Needed }\end{array}$ & - & 320 \\
\hline $\begin{array}{l}\text { Обизая стоимость кризисных коек / кресел } \\
\text { Total cost of Crisis Facility Beds / Chairs }\end{array}$ & $\$-$ & $\$ 93389555$ \\
\hline $\begin{array}{l}\text { Обслужено ежедневно одной мобильной бригадой } \\
\text { \# Served Per Mobile Team Daily }\end{array}$ & 4 & 4 \\
\hline $\begin{array}{l}\text { Количество необходимых мобильных бригад } \\
\text { \# of Mobile Teams Needed }\end{array}$ & - & 49 \\
\hline $\begin{array}{l}\text { Общее число эпизодов с мобильной бригадой } \\
\text { Total \# of Episodes with Mobile Teams }\end{array}$ & - & 51394 \\
\hline $\begin{array}{l}\text { Oбщая стоимость мобильных бригад } \\
\text { Total Cost of Mobile Teams }\end{array}$ & $\$-$ & $\$ 17248545$ \\
\hline $\begin{array}{l}\text { Число обслуженных уникальных индивидов } \\
\text { \# of Unique Individuals Served }\end{array}$ & 109211 & 160605 \\
\hline $\begin{array}{l}\text { Общая стоимость затрат на стационар и кризисное реагирование } \\
\text { Total Inpatient and Crisis Cost }\end{array}$ & $\$ 679537905$ & $\$ 385601121$ \\
\hline $\begin{array}{l}\text { Затраты отделения скорой помощи (\$1233 на острого пациента) } \\
\text { ED Costs (\$1,233 Per Acute Admit) }\end{array}$ & $\$ 134657717$ & $\$ 38743797$ \\
\hline $\begin{array}{l}\text { Общие затраты } \\
\text { Total Cost }\end{array}$ & $\$ 814195621$ & $\$ 424344918$ \\
\hline $\begin{array}{l}\text { Общая разница в затратах } \\
\text { Total Change Cost }\end{array}$ & & $-48 \%$ \\
\hline
\end{tabular}

Однако это лишь часть картины. Уровни помощи (LOCUS Levels of Care) помогают определить необходимый уровень помощи. Так люди получают то, что им нужно, а система экономит бюджет, сокращая число
This ensures people receive the treatment they need and the system saves money by reducing the number of people receiving a level of care that exceeds their need. 
людей, получающих уровень помощи, который превышает их потребности.

Калькулятор коек даёт более полный обзор кризисной системы (табл. 1). Он учитывает число острых стационарных коек, число кризисных коек, число занятых кресел для стабилизации состояния, число мобильных команд. Калькулятор проекций системы Crisis Now для штата Индиана показывают экономию средств, когда была применена система Crisis Now. Сокращение расходов составило свыше 390 миллионов - на $48 \%$.

Литература / Reference:

1. Nicks B.A., Manthey D.M. The Impact of Psychiatric Patient Boarding in Emergency Departments. Emergency Medicine International. 2012; Article ID 360308: 5 https://doi.org/10.1155/2012/360308

2. Stone D.M., Simon T.R., Fowler K.A., et al. Vital Signs: Trends in State Suicide Rate - United States, 1999-2016 and Circumstances Contributing to Suicide - 27 States, 2015. MMWR Mortal Wkly Rep. 2018; 67: 617-624.

3. WHO (2019, September 27). Suicide data. Retrieved from: https://www.who.int/mental_health/prevention/suicide/suicidepre vent/en/

4. Hepburn S. (2019, May 30). Misha Kessler on Why Behavioral Healthcare Must be Accessible to Students in a Crisis. Retrieved
The Bed Calculator provides a more indepth view of the crisis system (Table 1). It takes into account the number of Acute Inpatient Beds, the number of Crisis Beds, the number of Crisis Stabilization Chairs, and the number of Mobile Teams. The Crisis Now System Calculator Projections for the state of Indiana in the United States demonstrate the cost savings obtainable when the Crisis Now system is utilized. The savings amounts to over $\$ 390$ million, a cost reduction of 48 percent.

\section{CRISIS NOW: THE BUSINESS CASE RESULTING IN A TRANSFORMATION OF CRISIS CARE. THE EXPERIENCE OF ARIZONA IN THE UNITED STATES}

David W. Covington

RI International, Phoenix, USA; David.Covington@riinternational.com

\section{Abstract:}

Every day, emergency dispatchers receive thousands of calls for mental health crisis situations. In the majority of cases, it is a Police Officer who is the first contact and often has little option but to take them to Emergency Rooms or jail. Individuals can wait hours or even days for an opportunity to see a mental health professional. Many times, the person is released without receiving appropriate care or a recovery plan. In response to this situation, the National Action Alliance, based in the US, formed a crisis services task force who released "Crisis Now: Transforming Services is Within Our Reach" in 2016. To meet the challenge of changing crisis services proposed in the report, RI International partnered with NASMHPD and created the business case for Crisis Now to define the Crisis Now continuum of care. The difference made by the Crisis Now model led to an six times greater Crisis Clinical Fit to Need (CCFN) than was possible previous. It additionally equated to $\$ 37$ million in avoided costs/losses for the hospital Emergency Departments, reduction in the potential state inpatient spending of \$260 million, and saved the equivalent of 37 FTE Police Officers (calculated by Arizona data, 2017).

Keywords: crisis, suicide, crisis care, Crisis Now, Arizona, USA

Финансирование: Данное исследование не имело финансовой поддержки.

Financing: The study was performed without external funding.

Конфиикт интересов: Автор заявцяет об отсутствии конфцикта интересов.

Conflict of interest: The author declare no conflict of interest.

Статья поступима / Article received: 21.12.2019. Принята к пубиикации / Accepted for publication: 12.03.2020.

Для цитирования: Covington D.W. Crisis Now: бизнес-кейс, приведший к преобразованию кризисной службы. Опыт штата Аризона, США. Суицидология. 2020; 11 (1): 146-152. doi.org/10.32878/suiciderus.20-11-01(38)-146-152

For citation:

Covington D.W. Crisis Now: The business case resulting in a transformation of crisis care. The experience of Arizona in the United States. Suicidology. 2020; 11 (1): 146-152. (In Russ) doi.org/10.32878/suiciderus.20-1101(38)-146-152 